\title{
Institutionalizing Transparency and Accountability in Indian Governance: Understanding the Impact of Right to Information
}

\author{
Dr Roopinder Oberoi \\ Assistant Professor, Department of Political Science, University of Delhi, India
}

\begin{abstract}
Transparency is a powerful and leading concept. Transparency and accountability in administration is, in fact, sine qua non of participatory democracy. Government secrecy fosters disbelief of government on the part of the citizenry and transparency eliminates the wall of secrecy built against the common people by those holding in power. Transparency will not be accomplished unless we have open governance with accurate and verifiable information accessible.

As a concept, transparency is comparatively new to Government functioning in India. The foremost step to revolutionize this has been the enactment of Right to Information Act which enabled monitoring and accountability for every citizen as a right. R.T.I. Act is a significant landmark in the augmentation of the democratic system in the country. The Act makes it statutory for the latter to disclose all unclassified information when and where required by citizen.

However, the success of this Act requires ample enlightenment of those who hold authority and those who want to avail information for the betterment of their selves or that of the society at large. Those in authority need to be persistently reminded about their responsibilities and obligations under this Act until they get fully integrated into the democratic culture sans official knowledge barriers. On the other end of the spectrum there is the common citizenry who need to be conversant with the modalities for availing information under this Act. This paper aims at theoretical understanding of the concept of transparency and its inextricable link to accountability. India continues to be marred by scams and massive corruption despite the enactment of RTI. This is indicative of the complexity of the malaise and the obstinacy the problem. The paper explores the contour of Right to Information (RTI) and looks into the authority and responsibilities of Chief Information Commission of India in institutionalizing and accomplishing this empowering act. The article acknowledges the advancement accomplished to deepen democracy but is unquestionably not unconscious of the actuality where lot needs to be done to root transparency into the essentiality of the governance. Institutionalizing transparency and openness in governance, therefore, continues to be protracted and vexatious journey in India.
\end{abstract}

Keywords: Transparency; Deeping Democratic Institutions; Accountability; Right to Information; Chief Information Commission.

\section{Introduction}

Public governance relates to the process by which a society organizes its affairs and manages itself. In democracies, public governance is a complex matrix of relationship that exists between the institutions and civil society regarding the responsibility and accountability for the management and control of public resources and delivery of public services. Governance implies effective management of public resources, high level of accountability, and transparency and a free flow of information, control of corruption; significant citizen participation and equity are the quintessential principles of democratic institutions.

Since around the 1990s, "transparency" became a maxim for national governments, international institutions, and civil society groups around the world. Nobel prizes have been awarded for bringing attention to the importance of information in the functioning of the markets. George Akerlof, Michael Spence and Joseph Stiglitz received the Nobel Prize in 2001 for their analysis of how imperfect information can lead to market failures. Amartya Sen won the 1998 Nobel Prize for illustrating the role of information and "entitlement" in the functioning of the markets. His far-reaching research on famines in the great Bengal, Sahel, Bangladesh and Ethiopia showed that famines had occurred in years when the supply of food was not significantly lower than during previous years. The problem was not the scarcity of food but lack of information and "voice". (Ana Bellver and Daniel Kaufmann, World Bank, 2006) People will starve when their entitlement is not sufficient to buy the food necessary to keep them alive. The towering conceptual contributions of the Nobel-laureates in putting forth a framework linking the citizenry's right to know and to access to information with development are undisputable, and have already had a significant influence in various fields. (Ibid)

In fact, transparency is widely recognized as core principle of good governance. Free access to information is a key constituent in promoting transparency. But the information must be timely, relevant, accurate and complete for it to be used effectively. Transparency and accountability in Government are 
mutually reinforcing. However, actual implementation of transparency-related reforms on the ground, while not devoid of stellar examples and progress in some countries, remains checkered globally.

This swing from a default of secrecy to transparency is a very vital one. It not only indicates a concrete duty on the state to provide information as per the law, but can also be seen as an indication of a shift in the very conceptualization of the body politic. Formerly passive subjects of a state are re-imagined as active citizens with a legitimate interest in such information, and thus having an inherent right to it. Democracy necessitates an informed citizenry and transparency of information which are vital to its functioning and also to contain corruption and to hold Governments and their instrumentalities accountable to the governed. It provides a framework for an informed public to gain awareness of the interactions between institutions of government.

\section{What is "transparency"?}

Mitchell (1998: 109) defines transparency as the dissemination of regular and accurate information. Simply put, a transparent political regime is one that provides accurate information about itself, its operations, and the country as a whole, or permits that information to be collected and made available. Kopits and Craig (1998) identify transparency as "openness toward the public at large about government structure and functions, fiscal policy intentions, public sector accounts, and projections. It involves ready access to reliable, comprehensive, timely, understandable, and internationally comparable information on government activities so that the electorate and financial markets can accurately assess the government's financial position and the true costs and benefits of government activities, including their present and future economic and social implications."

Vishwanath and Kaufmann (1999) observe transparency as the "increased flow of timely and reliable economic, social and political information, which is accessible to all relevant stakeholders." Bellver and Kaufman (2005) pursue Florini (1999), making the study that can be seen as key to understanding transparency: "the release of information by institutions that is relevant to evaluating those institutions" (Florini, 1999, 5). As Bellver and Kaufman $(2005,5)$ put it, "Because transparency is a tool to facilitate the evaluation of public institutions, the information provided needs to account for their performance."

An organization's transparency can be measured by the "depth of access it allows," "the depth of knowledge about processes it is willing to reveal," and the "attention to citizen response" it provides ((Curtin \& Meijer, 2006, citing Welch \& Hinnant, 2003). "[T]he more transparent an organization is (via its web site or otherwise), the more it is willing to allow citizens to monitor its performance and to participate in its policy processes" (Curtin \& Meijer, 2006).

Transparency as a concept wraps event transparency ("open information about inputs, outputs and outcomes"), process transparency ("open information about transformations that take place between inputs, outputs, and outcomes"), real-time transparency (information released immediately), or retrospective transparency (information available only after time passes) (Hood, 2007). Transparent decisions should be "clear, integrated into a broader context, logical and rational, accessible, truthful and accurate, open (involve stakeholders), and accountable.” (Drew \& Nyerges, 2004)

Assessment of the accomplishment of transparency laws have been based on the processes (Neuman and Calland, 2007, Bookman and Amparan, 2009, Holsen and Worthy, 2010), outputs (Holsen and Pasquier, 2010,) and impacts (Transparency, 2008, Peisakhin and Pinto, 2008, Relly and Sabharwal, 2009) of such laws. The transparency of transparency (ToT) in process can be defined as the open and unobstructed communication of the rules and mechanism of the concepts and tool set in place to promote or to achieve transparency whether internally or externally underscoring the inherent rights/obligation of administrations and citizens alike.

Simply put, a transparent political regime is one that provides accurate information about itself, its operations, and the country as a whole, or permits that information to be collected and made available. Stiglitz (2002) argues that governments can have inducement both to restrict and facilitate the flow of information. Moreover, in numerous occasion the government is the sole repository (and/or producer) of these data, and it has complete discretion as to whether to release it or not. Governments also adopt a variety of domestic institutions (laws, regulations and procedures, such as administrative review) designed to regulate the flow of information. These include 'Freedom of Information Acts,', Protections of media and speech freedoms, or more generally protections of the public's 'right to know.'

Information is valuable to the electorate for democratic processes to function successfully, citizen have an interest in knowing about government actions and processes, allocation and redistribution decisions, market barriers and restrictions, tax and subsidy incidences and so on. Not only do these factors affect the economic performance of market activities, they affect the political support the voters may offer to incumbent policymakers. Greater transparency may bring about lower rates of political corruption because it can facilitate legal, administrative or electoral mechanisms of punishment. Transparency serves two other important functions: protection of individual rights and facilitation of individual involvement in governance. Also, transparent governance may create greater public trust and legitimacy in government actions. The public values 
transparency. Transparency is also an end in itself. Belief in the openness of government to regular inspection is so firmly ingrained in our collective consciousness that transparency has innate value.

\section{The Inextricable link between Transparency and Accountability}

Transparency and accountability are reciprocally supporting. Essentially the term accountability encapsulates three main elements; answerability- the need for justification of actions; enforcement- the sanction that could be imposed if the action or justification of actions is found to be unsatisfactory (Schedler, 1999).; and responsiveness - the ability of those held accountable to respond to the demands made (Posani and Aiyar, 2009). Interwoven in these core elements is the notion of transparency, which is defined as 'the degree to which information is available to outsiders that enables them to make informed decisions and or to assess the information made by insiders' (Florini, 2007:5).

Defined such, the links between the two are said to be fashioned along two axes- transparency of information is instrumental for demanding accountability because without information individuals cannot know the excesses being committed by the state. Further transparency of information is also seen as significant for motivating citizens to exercise 'voice' power. Voice power is defined as the capacity of citizens to pressurize the frontline officials in ensuring effective delivery of services (Goetz and Gaventa 2001). The role of transparency in strengthening 'say' and 'engagement' has been given particular emphasis. It is assumed that access to information mobilizes citizens for collective action and this in turn strengthens the incentive structure of frontline providers (ibid). In a capsule then, the recurrent theme seems to be greater transparency leads to more empowerment, which in the context of more participation amplifies 'voice' and the assertion of voice results in greater accountability (Aiyar et al, 2009).

Mendel (2004) lists the international and comparative standards that should underpin freedom of information legislation:

$>$ Principle 1. Maximum disclosure.

$>$ Principle 2.Obligation to publish.

$>$ Principle 3. Promotion of Open Government. Public bodies must actively promote open government.

$>$ Principle 4. Limited Scope of Exceptions. Exceptions should be clearly and narrowly drawn and subject to strict "harm" and "public interest" test.

$>$ Principle 5. Process to Facilitate Access. Requests for information should be processed rapidly and fairly and an independent review of any refusal should be available.

$>$ Principle 6. Individuals should not be deterred from making requests for information by excessive costs.

$>$ Principle 7. Meetings of public bodies should be open to the public.

$>$ Principle 8. Disclosure takes Precedence.

$>$ Principle 9. Protection for Whistleblowers.

Moreover, access laws to information will be ineffective if citizens and non-governmental organizations not have the capability to exercise their right of access or the resources to pursue complex requests. Likewise, there is little point in having a law that provides for the right to access to information if there is not clear and effective mechanism to enable citizens to use the law and if the content and benefits of the law have not been communicated through a broad communication campaign. (Ana Bellver and Daniel Kaufmann, World Bank, 2006)

Despite these linkages, scholars such as Jayal (2008) and Fox (2007) argue that while transparency is an important constituent for securing accountability, the link between the two is neither unassailable nor automatic. Further the exercise of 'voice' which is seen as a critical element for cementing this relationship is conditioned by various factors. Transparency of information while providing the opportunities and the material basis for the exercise of voice is not sufficient in impelling citizens to pressurize officials in demanding the effective delivery of services.

The extent to which measures to promote transparency can add towards fortification of voice, is predicated on 1) the manner and type of information displayed, and 2) the design of the transparency mechanism; including the responsiveness of the system and the institutional space available for follow up action and the awareness on the part of the citizenry of these avenues (Stirton and Lodge, 2001). Similarly whilst 'voice' is a necessary condition for accountability it alone is inadequate in delivering accountable relationships. Thus while citizens may be motivated to raise their demands it does not imply that power holders will be responsive to them. Factors which influence the translation of voice claims into effective accountability include; 1) the personal capacities of citizens 2) the nature of the political framework and more specifically the structure of the service delivery system (O’Neil, Foresti and Hudson, 2007)

In the context of the relationship between transparency and voice, the capacity of individuals to make use of information and demand accountability is predisposed principally by the approach in which information is supplied, whether it is functional and felicitous. If information is not made available in a relatable manner, 
average citizens would have to rely upon others for the demystification or sense-making of information, resulting in the disempowerment of some groups over others.

According to Fox (2007) there are principally two different types of information displays: Clear and Opaque. The criterion of 'Opaque' refers to the type of information which does not reveal how institutions actually behave in practice, in terms of how they make their decisions or the results of their actions. Clear displays on the other hand refers to access to information on institutional performance, official responsibilities and flow of public money. Clear transparency thereby sheds light on institutional behaviour, which permits interested parties to pursue strategies for constructive change (Ibid). The distinction between Opaque and Clear transparency mechanism thereby rests on the premise that if transparency policies are to meet the requirement of transforming institutional behaviour by allowing individuals to exercise greater control over the delivery of services, they need to be explicit in terms of 'who does what and who gets what' (Ibid: 668). Fox (2007) however cautions that the extent to which transparency initiatives are successful depend on a) responsive to the end users such that they can exercise some input into the decision making process and b) the extent to which end users are made to understand the actions they can potentially take.

Institutional framework, on the other hand is seen as an intervening variable between citizens' capacity to exercise voice and demand accountability. However while political legal systems which are constitutionally designed to be open and responsive may create the space for making claims for accountability, accountability of service delivery systems is ensured when certain basic elements are in place (World Bank, 2006).

Making government more open and transparent is a process involving three important areas of focus:

$>$ Right to information laws - this establishes the constitutional/legal right for a citizen to access the information that they want;

$>$ Proactive transparency - this commits governments to publishing as much information as possible in an accessible form;

$>$ Open data approach - this enables us to reconfigure government data into forms that provide useable and accessible information. (World Bank, 2006)

\section{Global Movement towards Transparency}

In 1990, 13 countries had right to information laws in place. Today this number stands at around 90. A further 53 countries either have draft legislation pending or strong lobbies for legislation. (Puddephatt \& Rebecca Zausmer 2011)

Figure 1: Countries in the world with Freedom of Information Acts

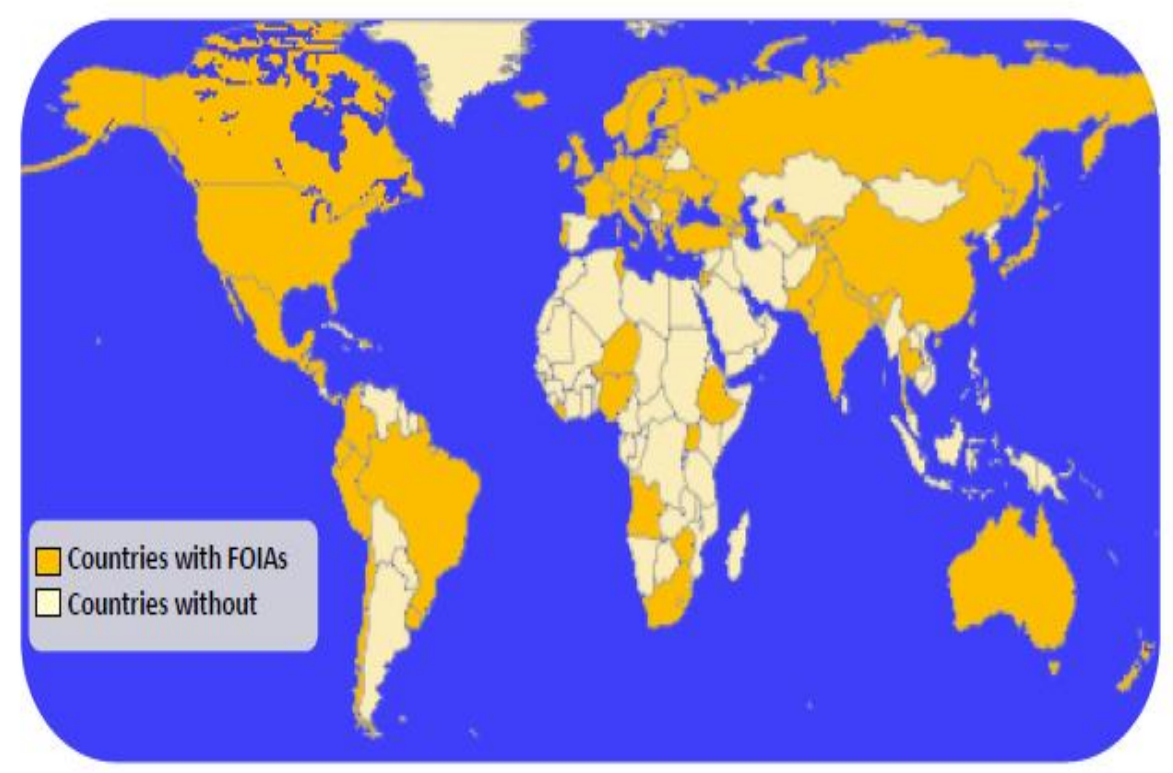

Source: Puddephatt, Andrew \& Zausmer Rebecca. (2011)

In Western Europe, 17 countries now have RTI acts, from the earliest adopter Sweden (1766) to the most recent ones including the UK (2000) and Germany (2005). A significant proportion of new right to information laws have come from Eastern Europe after the collapse of the Soviet Union and the wave of democratization in the 1990s. (Puddephatt \& Rebecca Zausmer 2011)

Advancement in the Global South is mixed. The Americas have revealed considerable interest in freedom of information. 19 of the Americas (excluding the US and Canada) have access provisions in federal laws/state laws. Brazil is the fresh addition to this list, passing its Access to Information Act on 22 November, 
2011. Furthermore, Mexico is heralded as a leader in the access arena not just regionally, but globally with 'one of the strongest laws in the world'. In Asia, the last ten years have seen a growing trend in RTI laws. India, passed its RTI law in 2005, is seen as a model right to information regime. (Puddephatt \& Rebecca Zausmer 2011) RTI laws are lacking in both Africa and the Middle East. In fact, the Middle East has only two countries with RTI laws - Jordan and Israel - and the Jordanian law is regarded as weak as its impetus came solely from the government and no input from civil society. In Africa there are now nine countries with RTI legislation: Angola (2002 2006); Ethiopia (2010); Liberia (2010); Niger (2011); Nigeria (2011); South Africa (2001); Tunisia (2011); Uganda (2006); Zimbabwe (2002). In Zimbabwe, though, this law is used to restrict access to information and freedom of expression rather than facilitate it. It is a tool for repression rather than openness and transparency. While in Latin America the news of a new Brazilian RTI legislation is cause for celebration, the news in Africa is less promising. The South African government is in the final phase of passing a new secrecy bill that undermines its access to information legislation and freedom of speech in the country. It is apparent that there remains significant gap, in both the Middle Eastern and African regions for a model national RTI regime that facilitates open government. (Puddephatt \& Rebecca Zausmer 2011)

\section{Institutions of Transparency in India}

The paradox in Indian Institutional framework to ensure transparency and thereby accountability is inescapable. The de jure policies might appear to be all in place, and yet in the de facto implementation and delivery, there is rampant corruption, absenteeism, indifference, incompetence, inefficiencies or outright failures. At the heart of these failures, is a systemic crisis of accountability. In fact, some observers have argued that the Indian state, its institutions, and the rules that govern them are structured to avoid accountability altogether (Mehta 2003, Saxena 2004). Transparency is sometimes in tension with responsiveness and representation in tension with both. The crucial point is that harmonizing the different components of accountability cannot be done by conceptual fiat. It is an empirical matter addressed by institutional design and the concrete work of politics.

"A popular government without popular information, or the means of acquiring it, is but a prologue to a farce or a tragedy or perhaps both. Knowledge will forever govern ignorance, and a people who mean to be their own governors, must arm themselves with the power knowledge gives." - James Madison, Former US President, 1822.

The early tidings of open and transparent government in India can be said to have begun with the landmark judgment of Justice P. N. Bhagawati of the Supreme Court of India in 1981, (Gupta S.P. vs Union of India (1982), Supreme Court of India, AIR 1982SC149) where, besides giving a general description of open government he stressed the need for increased disclosure in matters relating to public affairs. Noting that open government means 'information available to the public with greater exposure of the functioning of government which would help assure the people a better and more efficient administration' he went on to describe Open Government in India to be, "the new democratic culture of an open society towards which every liberal democracy is moving and our country (India) should be no exception".

The promulgation of Right to Information Act (2005) set the stage for the transparency in the functioning of the government and its various agencies. Under this Act, access to information from a public agency has become a statutory right of every citizen. In its enactment, it had been argued that the system of government in India is so opaque that ordinary citizens do not have much information about how decisions are made and how public resources are utilized. In effect, RTI Act is a vehicle for greater transparency about the manner of functioning of public agencies. There have been some 'major gains' in disclosure of information, as reported in media and research from time to time. According section 2 (j), 'right to information' includes the right to

- Inspection of work, documents, records;

- Taking notes, extracts or certified copies of documents or records;

- Taking certified samples of material;

- Obtaining information in the form of diskettes, floppies, tapes, video cassettes or in any other electronic mode or through printouts where such information is stored in a computer or in any other device. 
Table 1 Disposal of RTI Applications

\begin{tabular}{|c|c|}
\hline Situation & Time limit for disposing the application \\
\hline Information in normal course & 30 days \\
\hline Information concerning the life or liberty of a person & 48 hours \\
\hline Information if the application is received through APIO & 5 days added to above time periods \\
\hline $\begin{array}{l}\text { If application received after transfer from another public } \\
\text { authority: } \\
\text { - In normal course } \\
\text { - Information concerns the life or liberty of a person }\end{array}$ & $\begin{array}{l}\text { - Within } 30 \text { days of receipt by the concerned } \\
\text { - Wublic authority } \\
\text { - Within } 48 \text { hours of receipt by the concerned } \\
\text { public authority }\end{array}$ \\
\hline $\begin{array}{l}\text { Supply of information by organisations specified in the } \\
\text { second Schedule: } \\
\text { - If information relates to allegations of violation of } \\
\text { human rights } \\
\text { - If information relates to allegations of corruption }\end{array}$ & $\begin{array}{l}\text { - } 45 \text { days from receipt of application } \\
\text { - Within } 30 \text { days of receipt of application }\end{array}$ \\
\hline $\begin{array}{l}\text { Information relating to third party who has treated it as } \\
\text { confidential }\end{array}$ & $\begin{array}{l}\text { Provided after following certain prescribed } \\
\text { procedure given in the Act under Section II }\end{array}$ \\
\hline $\begin{array}{l}\text { Information where the applicant is asked to pay additional } \\
\text { fee }\end{array}$ & $\begin{array}{l}\text { Period between informing the applicant about } \\
\text { additional fee and the payment of fee excluded for } \\
\text { calculating the period of reply }\end{array}$ \\
\hline
\end{tabular}

Source: Analyzing the Right to Information Act in India; Policy Briefing Paper; 1/2010

The new Act comprises a single piece of legislation which is to be implemented by the Central and State Governments of India throughout the entire country at all levels of government. The fact that the same law will be supported by different sets of Rules in each jurisdiction and will not be coordinated by a single nodal Ministry leads to complications. As such, coordination is an important issue which Information Commissions, as champions of openness under the Act, need to constantly facilitate and promote as implementation and application of the law progresses.

According to the Report of Open Government Data in India, while government has initiated many egovernance initiatives, not many of them have resulted in publicly accessible databases. Fewer still of those publicly accessible databases are 'open' in terms of data reusability (technologically, in terms of machine readability and openness of formats), data reusability (legally), easy accessibility (via search engines, for persons with disabilities, etc.), and understandability (marked up with annotations and metadata). Putting out raw data will not suffice. To ensure the relevance of open government data, mechanisms have to be put in place to take its benefits to the common person and to marginalized communities, both by the government as well as by civil society organizations. Concrete steps on these lines will help realize the dream of Open data in the near future in India. The table below provides a comparative view regarding the RTI legislation in India as compared to other developed countries. Despite enactment of RTI in 2005 there still remains gap between openness and pinning accountability. 
Table 2: RTI Legislations: A Comparison - India vs Developed Nations

\begin{tabular}{|c|c|c|c|c|}
\hline Country & Sweden & UK & US & India \\
\hline $\begin{array}{l}\text { Constitutional } \\
\text { Protection }\end{array}$ & Protected & Not protected & Not protected & $\begin{array}{l}\text { Protected (by } \\
\text { interpreting) }\end{array}$ \\
\hline Legislation & $\begin{array}{l}\text { Freedom of the Press } \\
\text { Act } 1766\end{array}$ & FOl Act 2000 & FOIAct 1966 & RTI 2005 \\
\hline $\begin{array}{l}\text { Right of } \\
\text { Access }\end{array}$ & $\begin{array}{l}\text { Not limited by } \\
\text { nationality or } \\
\text { residence }\end{array}$ & $\begin{array}{l}\text { Not limited by } \\
\text { nationality or } \\
\text { residence }\end{array}$ & $\begin{array}{l}\text { Not limited by nationality } \\
\text { or residence. But with } \\
\text { exceptions }\end{array}$ & $\begin{array}{l}\text { Limited only to } \\
\text { citizens }\end{array}$ \\
\hline \multirow[t]{5}{*}{$\begin{array}{l}\text { Procedural } \\
\text { Guarantees }\end{array}$} & $\begin{array}{l}\text { Personal details of } \\
\text { the applicant + } \\
\text { reasons for request }\end{array}$ & $\begin{array}{l}\text { Personal details of } \\
\text { the applicant + } \\
\text { description of the } \\
\text { information desired }\end{array}$ & $\begin{array}{l}\text { Personal details of the } \\
\text { applicant + description of } \\
\text { the information desired }\end{array}$ & $\begin{array}{l}\text { Only contact details } \\
\text { required }\end{array}$ \\
\hline & $\begin{array}{l}\text { No specific timelines, } \\
\text { requests dealt quickly } \\
\text { and promptly }\end{array}$ & $\begin{array}{l}\text { Has a longer set of } \\
\text { time limits }\end{array}$ & $\begin{array}{l}\text { Special time limits apply } \\
\text { to cases of compelling } \\
\text { need }\end{array}$ & $\begin{array}{l}48 \text { hour time limit } \\
\text { applies to protect life } \\
\text { or liberty }\end{array}$ \\
\hline & $\begin{array}{l}\text { No mention about } \\
\text { transfer of requests } \\
\text { or consultation with } \\
\text { third parties }\end{array}$ & $\begin{array}{l}\text { Direct transfers of } \\
\text { request are } \\
\text { permitted }\end{array}$ & $\begin{array}{l}\text { No mention about } \\
\text { transfer of requests or } \\
\text { consultation with third } \\
\text { parties. In practice, } \\
\text { transfer of requests is } \\
\text { common }\end{array}$ & $\begin{array}{l}\text { Allow transfers of } \\
\text { request }\end{array}$ \\
\hline & $\begin{array}{l}\text { Inspection of } \\
\text { document provided } \\
\text { free of charge. Rates } \\
\text { apply when copies } \\
\text { exceed nine pages }\end{array}$ & $\begin{array}{l}\text { Contains two } \\
\text { separate systems for } \\
\text { fees, one for } \\
\text { ordinary request and } \\
\text { another for more } \\
\text { complicated requests }\end{array}$ & $\begin{array}{l}\text { Contains provisions } \\
\text { relating to fees, } \\
\text { distinguishing between } \\
\text { commercial, educational } \\
\text { or scientific institutions, } \\
\text { and other requesters }\end{array}$ & $\begin{array}{l}\text { Access upon payment } \\
\text { of fee, including for } \\
\text { information provided } \\
\text { in electronic format. } \\
\text { No fec for BPL }\end{array}$ \\
\hline & $\begin{array}{l}\text { When information } \\
\text { refused, notice sent } \\
\text { giving reasons }\end{array}$ & $\begin{array}{l}\text { When information } \\
\text { refused, notice sent } \\
\text { giving reasons }\end{array}$ & $\begin{array}{l}\text { Refusal notice includes } \\
\text { name of the deciding } \\
\text { official, quantity of } \\
\text { information denied }\end{array}$ & $\begin{array}{l}\text { When information } \\
\text { refused, notice sent } \\
\text { giving reasons and how } \\
\text { to lodge an appeal }\end{array}$ \\
\hline $\begin{array}{l}\text { Duty to } \\
\text { Publish }\end{array}$ & $\begin{array}{l}\text { No obligation to } \\
\text { publish. In practice, } \\
\text { information provided } \\
\text { via websites }\end{array}$ & $\begin{array}{l}\text { No information } \\
\text { regarding publication }\end{array}$ & $\begin{array}{l}\text { Certain information } \\
\text { published in the Federal } \\
\text { Register, while others } \\
\text { available for inspection }\end{array}$ & $\begin{array}{l}\text { Extensive rules on } \\
\text { proactive or routine } \\
\text { publication and regular } \\
\text { updates }\end{array}$ \\
\hline Exception & $\begin{array}{l}\text { Unique exception - } \\
\text { relating preservation } \\
\text { of animal/plant } \\
\text { species }\end{array}$ & $\begin{array}{l}\text { Contain rare or } \\
\text { peculiar exceptions } \\
\text { relating to the royal } \\
\text { family }\end{array}$ & $\begin{array}{l}\text { Contain rare or peculiar } \\
\text { exceptions - relating to } \\
\text { information about oil } \\
\text { wells }\end{array}$ & $\begin{array}{l}\text { Do contain rare or } \\
\text { peculiar exceptions - } \\
\text { information which } \\
\text { would incite offence }\end{array}$ \\
\hline
\end{tabular}

Source: Analyzing the Right to Information Act in India; Policy Briefing Paper; 1/2010 
Table 3: RTI Legislations A Comparison: India vs South Asia

\begin{tabular}{|c|c|c|c|c|}
\hline Country & Bangladesh & Nepal & Pakistan & India \\
\hline $\begin{array}{l}\text { Constitutional } \\
\text { Protection }\end{array}$ & $\begin{array}{l}\text { Protected (by } \\
\text { interpreting) }\end{array}$ & Protected & Protected & Protected (by interpreting) \\
\hline Legislation & RTI Act, 2009 & RTIAct, 2007 & FOI Ordinance, 2002 & RTI. 2005 \\
\hline $\begin{array}{l}\text { Information } \\
\text { about } \\
\text { private } \\
\text { bodies }\end{array}$ & $\begin{array}{l}\text { Private organisation } \\
\text { running on foreign or } \\
\text { government funding/ } \\
\text { exchequer; } \\
\text { organisation } \\
\text { undertaking public } \\
\text { functions under } \\
\text { contract with } \\
\text { government or public } \\
\text { organisation }\end{array}$ & $\begin{array}{l}\text { Body receiving } \\
\text { grants from the } \\
\text { government: } \\
\text { NGO running } \\
\text { on foreign or } \\
\text { government } \\
\text { funding or } \\
\text { international } \\
\text { organisation }\end{array}$ & No provisions & $\begin{array}{l}\text { Body owned, controlled or } \\
\text { substantially financed and } \\
\text { NGO funded directly or } \\
\text { indirectly by the government; } \\
\text { private bodies regulated by } \\
\text { public authorities }\end{array}$ \\
\hline $\begin{array}{l}\text { Proactive } \\
\text { Disclosure }\end{array}$ & $\begin{array}{l}\text { Too limited. Allows } \\
\text { only four kinds of } \\
\text { information } \\
\text { voluntarily }\end{array}$ & $\begin{array}{l}\text { Provides for } 12 \\
\text { kinds of } \\
\text { information } \\
\text { voluntarily }\end{array}$ & $\begin{array}{l}\text { Too limited. Provides only } \\
\text { five kinds of information } \\
\text { voluntarily }\end{array}$ & $\begin{array}{l}\text { Provides for } 17 \text { kinds of } \\
\text { information voluntarily }\end{array}$ \\
\hline Exemptions & 20 exemptions & $\begin{array}{l}5 \text { categories of } \\
\text { exemption }\end{array}$ & $\begin{array}{l}4 \text { categories of exemption } \\
+9 \text { exemptions related } \\
\text { to the type of record. } 5 \\
\text { additional grounds for } \\
\text { refusal }\end{array}$ & $\begin{array}{l}10 \text { exemptions }+1 \text { additional } \\
\text { ground for refusal (infringes } \\
\text { copyright) }\end{array}$ \\
\hline $\begin{array}{l}\text { Public } \\
\text { Interest } \\
\text { Disclosure }\end{array}$ & No provision & No provision & $\begin{array}{l}\text { No public interest } \\
\text { override. Government } \\
\text { can refuse to disclose in } \\
\text { public interest }\end{array}$ & $\begin{array}{l}\text { Exempted information's can } \\
\text { be disclosed if public interest } \\
\text { outweighs harm to } \\
\text { protected interests }\end{array}$ \\
\hline $\begin{array}{l}\text { Fee } \\
\text { Exceptions }\end{array}$ & $\begin{array}{l}\text { Government in } \\
\text { consultation with ICs } \\
\text { may exempt from } \\
\text { paying fee }\end{array}$ & No exemption & $\begin{array}{l}\text { Fee as it may be } \\
\text { prescribed but with aim } \\
\text { of providing information } \\
\text { promptly and at the } \\
\text { lowest reasonable cost }\end{array}$ & $\begin{array}{l}\text { Exempted for those below } \\
\text { poverty line.Also free if the } \\
\text { public authority fails to } \\
\text { comply with time limits }\end{array}$ \\
\hline $\begin{array}{l}\text { Urgent } \\
\text { Request }\end{array}$ & $\begin{array}{l}\text { Relating to life and } \\
\text { death, arrest and } \\
\text { release from jail. } \\
\text { Within } 24 \text { hours }\end{array}$ & $\begin{array}{l}\text { Relating to } \\
\text { defence of } \\
\text { human life. } \\
\text { Within } 24 \text { hours }\end{array}$ & No Provision & $\begin{array}{l}\text { Relating to life and liberty of } \\
\text { a person. Within } 48 \text { hours }\end{array}$ \\
\hline $\begin{array}{l}\text { Protection } \\
\text { for Whistle- } \\
\text { blowers }\end{array}$ & $\begin{array}{l}\text { No protection to } \\
\text { whistleblowers. } \\
\text { Protection to officials } \\
\text { for anything done in } \\
\text { good faith under the } \\
\text { Act }\end{array}$ & $\begin{array}{l}\text { Partial } \\
\text { protection } \\
\text { provided }\end{array}$ & $\begin{array}{l}\text { No protection to } \\
\text { whistleblowers. } \\
\text { Protection to officials for } \\
\text { anything done in good } \\
\text { faith under the Act }\end{array}$ & $\begin{array}{l}\text { No protection to } \\
\text { whistleblowers. Protection } \\
\text { to officials for anything done } \\
\text { in good faith under the Act. } \\
\text { However, the Public Interest } \\
\text { Disclosure (Protection of } \\
\text { Informers) Bill } 2010 \text { is } \\
\text { before the Parliament. }\end{array}$ \\
\hline
\end{tabular}

Source: Analyzing the Right to Information Act in India; Policy Briefing Paper; 1/2010

The table 3 provides a comparative perceptive regarding the enactment of RTI in South Asia and the difference between them in terms of thrust and focus of transparency legislation along with variation and dissimilarity in the quality and quantity of disclosure. The RTI activist and whistleblowers in South Asia continue to be vulnerable. So lot needs to be done to institutionalize openness in governance in Asian countries which lag behind the developments taking place in Europe and USA. There is also disinclination on the part of political leadership and bureaucrats to empower people with this essential democratic tool which will ensure transparent and accountable governance. 
The Second Administrative Commission 2008, Government of India has, after comprehensive studies into the working of government, made wide-ranging recommendations in its detailed reports, among others, on the right to information, citizen centric service delivery, local government, e-Governance etc. Some of the recommendations aim to help advance the basis of transparency, improve citizen centric service delivery, and participatory governance. These suggestions in brief relate to:

Suo motu disclosures under the RTI Act, 2005 should not be confined to the seventeen items provided in Section 4(1) of that Act but other subjects where public interest exists should also be covered.

Citizens' Charters should be made effective by stipulating the service levels and the remedy if these service levels are not met.

Regular citizens' feedback, survey, and citizens' report cards should be evolved by all government organizations for gauging citizens' responses to their services. These should be used as inputs for improving organizational efficiency.

Citizens should be actively involved in all stages of the welfare and development programs implemented by the government. Social audit should be made mandatory for all developmental programmes and be institutionalized for improving local service delivery.

Evaluation tools for assessing the performance of local bodies should be devised wherein citizens should have a say in the evaluation. Reward schemes should be introduced to incentivize citizen's initiatives School awareness programmes should be introduced, highlighting the importance of ethics and means of combating corruption. Citizens may be involved in the assessment and maintenance of ethics in important government institutions and offices.

Alongside action on the sound recommendations of the Commission, attention of the Central and State governments have to turn towards added meaningful and systematic efforts to strengthen freedom of information and participatory governance. The right approach to creating an open and transparent government is highly dependent on the country's democratic maturity and local context. Any move toward openness needs to be tailored to local conditions.

Effectively forming a system of openness is also not just a technical tick-box process. All reforms operate in a political context that can either drive or hinder reform. Political will is integral to creating open government. If the political will is not there already, then it needs to be generated or nurtured even. At the same time there needs to be a set of competent and committed public officials to create and manage the information systems for an open government. Just as important too is the involvement of a strong civil society who can put pressure on government and raise public awareness and support. Buy-in from all three sets of actor is crucial. Understanding the Chief Information Commissions Role and Responsibilities.

\section{The Hub of Transparency}

The Chief Information Commission (CIC) was established in 2005 and came into operation in 2006. Information Commissions sit at the crossroads between the rights of the public and the duties of officials. As such, it is essential that their judgments are consistent, well justified and can stand up to scrutiny - by the courts, the public and officials. At a minimum, all decision notices need to be collected internally into a central database, so that Commissioners and staff can easily refer back to previous decisions. Decisions need to be collected and filed even if they are issued summarily as a short order, as well as when they involve complex legal points and take the form of more detailed judgments. State information commissions have also been setup, thus giving practical shape to the 2005 Right to Information (RTI) Act. It is expected that the CIC will help spread the culture of public seeking information under the RTI and expose wrong doings.

One of the Information Commissions' most important roles is to handle appeals and complaints made under the Act. While an internal appeals mechanism is available as an inexpensive first opportunity under Section 19(1), oversight by Information Commissions which are independent of government is one of the most important safeguards included in the Act to ensure compliance with the law. By setting strong precedents in favor of openness, the Information Commissions operates to tackle entrenched cultures of secrecy that may continue to impact on openness under the Act.

When handling cases, it is important that Information Commissions keeps in mind the law's objective of promoting open government via maximum disclosure of information. In this context, it is important to recognize that the passage of the RTI Act symbolizes the Government's recognition that information disclosure is in the public interest.

Section 19(10) of the Act specifically requires that Information Commissions, and/or the Government nodal agencies are responsible for administering the RTI Act, and they will need to develop Rules which provide more detail on how an appeal will be made and processed. Some jurisdictions have already promulgated appeal rules.

Section 18(1) gives Information Commissions a very broad review remit to consider issues regarding disclosure, but regarding the calculation of fees, forms of access, imposing penalties and awarding 
compensation. Section 24(1) also gives Information Commissions a role in determining when information should be released by intelligence or security agencies exempted under Section .24(1) where it is claimed that the information sought "is in respect of allegations of violations of human rights". As a consequence of the breadth of the oversight remit of Information Commissions, internal procedural guidelines also need to address the different challenges that are thrown up by the different types of cases the Commissions will handle.

Section 19(5) of the Act specifically places the burden of proving that withholding information was justified onto the official who denied the request. In practice, this means that a requester only needs to interact with the Commission after the official withholding the information has first been questioned, because the burden is on the official to show the Commission that they were not wrong.

It is crucial that the Information Commission remains user-friendly and does not turn into another overly legal forum which is dominated by lawyers. Although the Commission does have the powers of a civil court under s.18(3) of the Act, nonetheless, the Commission is not expected to operate like a court. The main goal of setting up the Commissions was to provide an alternative to the courts which was cheap and easy to use for ordinary people.

It is critical that Information Commissions can be easily utilized by any member of the public, not just those who can afford sophisticated legal representation. In the event that officials engage legal counsel, the Information Commission, as an openness champion, needs to be proactive in ensuring that arguments in favour of disclosure are not overlooked simply because the requester is not present or has not used a lawyer. This approach focuses on ensuring that the fundamental constitutional right to information is properly enforced rather than simply turning hearings into a competition as to which party has the resources and skills to make a better argument.

Most importantly, s.19(8) includes a catch all phrase which enables Information Commissions to "require the public authority to take any such steps as may be necessary to secure compliance with the provisions of this Act". This clause, when combined with s.19(7) - which makes it unequivocal that the decisions of the Central and State Commissions are binding. It makes it obvious that Commissions have the statutory clout to be champion of openness and accountability, keeping in view the objectives and spirit of the law.

It is expressed that a matter of concern in the Act is that at present it contains no time limit for the disposal of appeals by the Information Commission, whereas section 19(6) requires Departmental Appellate Authority to dispose of appeals within 30-45 days. Preferably, the similar time limit of 30-45 days which is given to Departmental Appellate Authorities under s.19(6), should be assumed by Information Commissions. International best practice supports the establishment of a legal unit, or at least the employment of a legal expert, which will vet all decisions before they are issued, to ensure that they accord with the Act and common law generally. For example, the Act contains exemptions for information available to a person in his "fiduciary relationship", disclosures which would constitute a "contempt of court", and "trade secrets and intellectual property" - all of which are terms which have agreed legal meanings. It is important that Commissions take account of how these terms have already been interpreted by courts.

Section 25(3) specifically requires that Information Commissions produce annual reports through their Annual Reports; Information Commissions can provide a holistic picture of the status of compliance with the Act. They can highlight areas of good and bad practice, lessons learned and innovations which could be replicated. They can also pinpoint areas for reform.

Annual reports provide significant prospect to draw attention to RTI implementation issues. The statistics collected in the Annual Report can be an important monitoring tool for heads of public authorities, nodal agencies and the Information Commissions to regularly assess whether authorities are meeting their obligations under the Act. They can be used to identify any public authorities which perhaps require additional training or systems support - for example, because statistics show that they are regularly missing deadlines for disposing of applications or appeals.

At the time the Annual Report is tabled in Parliament, Information Commissions issues a press release summarising the highlights and setbacks in terms of functioning. Publicity is vital means of encouraging Governments to take action to address implementation deficiencies. In keeping with the strong proactive disclosure requirements in the Act at s.4, Annual Reports should be made available for scrutiny at every public authority, so that all members of the public can easily uncover the lacunas in the Act while it is being implemented.

It is essential that awareness raising and implementation strategies take account of the local needs of communities, as this makes it possible that the community feels a sense of "ownership" of the RTI and will identify its significance to their lives. In this milieu, experience has shown that strategies which promote government-community implementation partnerships can be principally constructive. Right to Information Councils is one mechanism for promoting additional community engagement with the Act. 
In other jurisdictions, Information Commissions have also set up Government-Civil Society Advisory Committees, drawing together representatives from civil society, the private sector and the media with officials and Commission staff to make recommendations for improvements and identify gaps in implementation and access in practice. This can be a valuable means of catalyzing civil society organizations to assume their own public awareness activities, as they consider that they have a direct stake in ensuring that implementation efforts are effective. In India, civil society groups have been particularly energetic in raising awareness of the Act, and their efforts may well be supported and endorsed by Information Commissions.

But, the experiences of ordinary citizens in most parts of the country have not always been very encouraging. A recent study (PRIA, 2008) on implementation of RTI Act in 12 states concluded:

a) information about who the designated Public Information Officers (PIOs) were in the district was not available in $90 \%$ of the districts;

b) nearly half of all respondents felt that PIOs were not at all cooperative in giving information even when asked (Kerala and MP behaving worse than UP, Bihar, Orissa and Haryana);

c) self-disclosure mandated under section 4 of the RTI Act was not made in $90 \%$ of the districts in these states. (PRIA, 2008)

One of the key necessities of this Act is self-disclosure of information in public domain. It is implicit that if satisfactory information is accessible, citizens can demand services and claim rights due to them from appropriate authorities and officials. The state of self-disclosure is relatively meager nationwide.

Another recent study conducted by PRIA and CHRI (2009) about status of self-disclosure in the arena of food security showed that Food Corporation of India and PDS (civil supply departments) have reasonably clear web-based self disclosure at national level. But, the quality and accessibility of such self-disclosed information at district level becomes extremely insufficient and non-existent. This implies that an ordinary citizen desirous of accessing food from the PDS system cannot get any comprehensible information from the system of self-disclosure currently being practiced in these states (including Karnataka, Gujarat and HP, which are generally deemed to be better governed states). Disclosure of information at state or national levels only, mostly in English language, and largely through only web-based tools have resulted in systematic exclusion of the very same citizens in whose name and interests' right to information has been enacted.

Transparency is indispensable for making the system of public service delivery effectual; it enables information in the hands of the citizens in a way that they may be able to claim their entitlements. However, mere knowledge of what entitlements are, and who is responsible for fulfilling them, is not adequate in ensuring that public services are sufficiently and effectively delivered to the 'intended' beneficiaries. There is a risk also that the opening up government becomes only a superficial process. Access to information laws can become merely 'paper' laws if they are not then appropriately implemented or are undermined by other laws. The right mechanisms to ensure implementation are just as imperative as the laws themselves.

By proactively publishing information governments have the potential to satisfy the information needs of the public en masse rather than just the individual. Not only does this make it easier for citizens to locate and access public information, but it diminishes the administrative load of frequent information requirements placed on public bodies. Proactive disclosure requires information management systems that facilitate in making government open and efficient. This in turn deepens democratic system and eliminates trust deficit which seems to be the trend in many countries. On the other hand it also assists government to recognize the concerns of people it governs. ICTs or e-governance have made it easier to systematize and make public large amounts of government information. And open data proposals allow information to be presented in ways that are functional and comprehendible to all. The culture of secrecy is one of the foremost barriers to opening up government. This culture permeates government and officials who believe that information is their source of supremacy and power. This needs to be upturned and dismantled. Creating a culture of candidness is, therefore, a fundamental move towards operationalizing open governance system. This requires going beyond the laws. At the same time, the public needs to be trained about the right to information and how to exercise this right. Only then will they embark on to insist on it.

\section{Conclusion}

The functioning of institutions of transparency is undergoing a paradigm change. Focus has shifted from secrecy to transparency, from working in isolation to working with the people, from arbitrariness to accountability for actions. These include emphases on substantive improvements in open government laws and governmental compliance with them, especially in terms of the timeliness and comprehensibility of disclosures, as well as on strengthening institutions that can provide more informed and rigorous resolutions of informational disclosure disputes. There is a general consensus in India that these institutions of transparency taken singly and collectively, have underperformed.

The new churnings in civic associations in India, and newer hybrid means by which they are demanding responsiveness from the state, the Decentralization and increased 'sightings of the state' (Corbridge 
et al 2005), the Right to Information Legislation - all present the potential to open up newer opportunities for empowerment of people, and for their claims for a transparent and accountable government. (Posani and Aiyar 2009)

In conclusion, rent seeking and resource dissipating activities are a subversion of the will of the voters, facilitated by obscure policymaking processes. Transparency Institutions restricts rent creation and diversion by forcing democratically elected policymakers to be accountable to the citizen. However, institutions created to strengthen the link between transparency and accountability is neither automatic nor unassailable. The institutional links shared between transparency and accountability measures allows for citizens to access and use the information in understanding how the institutions are functioning; in lodging complaints if the procedures are followed or if there is violation on account of probity or denial of essential entitlements to citizens through mechanisms of grievance redressal. However, even if transparency procedures create the opportunity for the exercise of voice, the translation of voice into accountability needs additional analysis of the ways in which transparency and accountability measures are premeditated, the social and institutional factors which impact such relations and empower citizens with the competence to apply their voice and insist accountability from the state.

\section{References}

[1]. Ackerman, J., (2004), 'Co-Governance for Accountability: Beyond "Exit"' and "Voice',', World Development 32(3): 447-463

[2]. Banerjee, A., Banerji, R., Duflo, E., Glennerster, R. and Khemani, S., (2006) 'Can Information Campaigns Spark Local Participation and Improve Outcomes? A Study of Primary Education in Uttar Pradesh, India', World Bank Policy Research Working Paper 3967

[3]. Blumkin, Tomer and Gradstein, Mark (2002). Transparency Gloves for Grabbing Hands - Politics and (Mis) Governance.

[4]. Central Information Commission; (2006) Annual Report 2005-2006 Ministry of personnel, public grievances \& Pensions; Government of India ; New Delhi

[5]. Curtin, D. \& Meijer, A. J. (2006). Does transparency strengthen legitimacy? Information Polity: The International Journal of Government \& Democracy in the Information Age, 11(2), 109-122.

[6]. D. Kapur \& P.B. Mehta (2005) Public Institutions in India -Performance and Design, New Delhi: Oxford University Press.

[7]. Florini, A., (2007) "Introduction: The Battle Over Transparency", in Anne Florini edited. The Right to Know: Transparency for an Open World, New York. Columbia University Press, pp. 5

[8]. Fox, J. (2007), The Uncertain Relationship between Transparency and accountability', Development in Practice, Vol. 17(4/5), pp. $663-671$

[9]. Goetz, A. M. and Gaventa, J (2001) 'Bringing Citizen Voice and Client Focus into Service Delivery'. IDS Working Paper 138, Institute of Development Studies, Brighton.

[10]. Hood, C. (2007). What happens when transparency meets blame-avoidance? Public Management Review, 9(2), 191-210.

[11]. Jayal, N., (2008), 'New Directions in Theorizing Social Accountability?' IDS Bulletin 38(6), Institute of Development Studies, Brighton, pp. 105-110

[12]. Jenkins, R. and Goetz, A. (2009) 'Accounts and Accountability-Theoretical Implications of the Right to Information Movement in India', Third World Quarterly, Vol. 23(3).

[13]. Joshi, A., (2008) 'Producing Social Accountability? The Impact of Service Delivery Reforms' IDS Bulletin 38(6), Institute of Development Studies, Brighton, pp. 10-17

[14]. Kaufman, Daniel (2005). Transparency: Initial Empirics and Policy Applications. Washington DC: World Bank Institute.

[15]. Koppell, J. G. S. (2005). Pathologies of Accountability and the Challenge of "Multiple Accountabilities Disorder." Public Administration Review, 65(1), 94-108.

[16]. Laver, Michael and Ken Shepsle. (1999.) "Government accountability in a parliamentary democracy." In Adam Przeworski, Susan Stokes and Bernard Manin (eds.), Democracy, Accountability, and Representation, Cambridge University Press, Cambridge.

[17]. Mitchell, Ronald B. (1998). "Sources of Transparency: Information Systems in International Regimes." International Studies Quarterly 42(1):109-130.

[18]. McMahon, Tom (1996). Access to Government Information: A New Instrument for Public Accountability. In Government Information in Canada/Information Gouvernementale au Canada, Volume 3, number/numéro 1 (summer/été)

[19]. Meade, E. E. \& Stasavage, D (2008). Publicity of debate and the incentive to dissent: Evidence from the US Federal Reserve. Economic Journal, 118(528), 695-717.

[20]. Mendel, T. (2004), Freedom of Information: A Comparative Legal Survey, UNESCO.

[21]. Morris Jones, W.H. (1957). India's Parliament. Allen and Unwin, London.

[22]. Neyland, D. (2007). Achieving transparency: the visible, invisible and divisible in academic accountability networks. Organization, 14(4), 499-516.

[23]. Posani and Aiyar (2009) State of Accountability: Evolution, Practice and Emerging Questions in Public Accountability in India. AI Working Paper No. 2, May.

[24]. PRIA, (2008). Assessing Information under RTI: Citizens' Experiences in 10 States.

[25]. Puddephatt, Andrew \& Zausmer Rebecca. (2011). Towards open and transparent government International experiences and best practice; Global Partners and Associates, December global-partners.co.uk/.../Towards-open-and-transparent-governmentInternational

[26]. Roy, A. and De, N. (2009) 'NREGA: Breaking New Ground', Delhi Compass Blog, The Hindu Newspaper, 21st June 2009, [online] Available at http://blogs.thehindu.com/delhi/?p=24233

[27]. Roy, Aruna and Dey, Nikhil (2001). The Right to Information: Facilitating People's Participation and State Accountability.

[28]. Sahgal Gayatri; Unpacking Transparency and Accountability Measures - A Case Study of Vijaipura Panchayat, Rajasthan

[29]. Sen, A. (1981), Poverty and Famines: An Essay on Entitlement and Deprivation, Oxford University Press.

[30]. Sharma Madhu Sudan \& George Cheriyan (2010) Analyzing the Right to Information Act in India; Policy Briefing Paper; CUTS International www.cuts-international.org/.../pdf/Analysing_the_Right_to_Information.

[31]. Stiglitz, J. E. (1999), "On Liberty, the Right to Know and Public Disclosure: The Role of Transparency in Public Life", Oxford Amnesty Lecture.

[32]. Stiglitz, J. E. (2002). Transparency in Government. In The Right to Tell. Washington DC: The World Bank. 
[33]. United Nations Development Programme Bureau for Development Policy, (2006) A Guide to Measuring the Impact of Right to Information Programmes. Democratic Governance Group; Practical Guidance Note.

[34]. Vishwanath, T. and D. Kaufmann. (1999). Towards Transparency in Finance and Governance. Washington DC: The World Bank.

[35]. Vleugels, R., (2011) Overview of all FOI laws, Fringe (Special Issue 9 October) [online] http://right2info.org/laws

[36]. http://cic.gov.in/ http://righttoinformation.gov.in/rti-act.pdf

[37]. http://righttoinformation.gov.in/rti-actinhindi.pdf

[38]. http://www.freedominfo.org/regions/east-asia/india/

[39]. Guide on Right to Information Act, 2005, Government of India. 〈http://rti.gov.in/RTICorner/Guideonrti.pdf>

[40]. History of Rising RTI in India < http://www.nyayabhoomi.org/treatise/history/history1.htm>

[41]. Global Trends on the Right to Information: A Survey of South Asia. http://www.article19.org/pdfs/publications/south-asia-foisurvey.pdf

\section{Brief Bio Note}

Dr (Ms) Roopinder Oberoi is Assistant Professor at Kirori Mal College; Department of Political Science, University of Delhi, India. She specializes in the area of Political Science and Public Administration. She has taught at Delhi University for 8 years. In the Year 2009 she was awarded a Post-Doctorate Research Fellowship by the University Grant Commission. She has contributed nearly 25 papers in various national and international journals in the field of Public Administration, Political Science; Governance; Corporate Governance and Corporate Social Responsibility. 